\title{
English for General International Business Law Course Construction in Chinese General Local Universities
}

\author{
Wenjun Wang \\ Foreign Language School \\ Kunming University \\ Kunming, China \\ wwj-201@163.com
}

\begin{abstract}
Guidelines on College English Teaching, released by China's Ministry of Education, guides the future college English teaching. In this document, English for Specific Purposes is regarded as one of the 3 key curriculums. It is under this background Kunming University explores the feasibility of ESP education in general local universities by taking English for General International Business Law as a breakthrough. KU constructed the course and implemented it. During the process of teaching, KU kept adjusting the course construction by adding CET-6 and legal listening and speaking. After a semester's teaching practice, $\mathrm{KU}$ has reaped some early harvest and proved the feasibility of ESP education in general local universities. The experience and data collected together the coming results of CET-6 will help to shape the course construction model of ESP in Chinese general local universities.
\end{abstract}

Keywords-ESP; International business law; course construction; local university; CET-6

\section{INTRODUCTION}

In 2017, China's Ministry of Education released Guidelines on College English Teaching (GCET). GCET replaced the former Basic Requirements for College English Teaching which used to the criteria of college English teaching. Namely, from now on, for all the universities in China, GCET will serve as the guidelines for their future college English syllabus formulation, college English course construction and evaluation [1]. In the same year, Yunnan Provincial Education Department organized the Declaration of “2017 College Foreign Language Teaching Reform Program”. Kunming University(KU), a Chinese general local university, has been considering the courses construction of English for Specific Purposes (ESP), therefore, it declared a program "English for General International Business Law Course Construction", which was approved as a key program. Currently, the program is progressing smoothly and has gained some early harvest in ESP course construction for general local universities.

\section{AN INTRODUCTION ABOUT ESP COURSE IN GCET}

Before GCET, another document also stipulated by China's Ministry of Education, Basic Requirements for

This paper is sponsored by Yunnan Provincial Education Department as an outcome of the Program "2017 College Foreign Language Teaching Reform Program”.
College English Teaching, had governed Chinese college English teaching for a decade. The name of the this document already suggested that it was a compulsory one, namely, all the universities in China had to follow it. But the truth is that there are so many universities in China which vary a lot in faculty, students, teaching facilities and so on. It is unreasonable for all the universities to follow the same requirements. Therefore, the new document GCET overturns the old one and uses "guidelines" to replace "requirements".

According to GCET, college English can be divided into 3 teaching levels: basic, enhanced, developed, and 3 curriculums: general English (GE), English for specific purposes (ESP) and Cross-Cultural Communication (CCC) in the forms of compulsory courses, compulsory optional courses and optional courses.

GCET points out that ESP courses, oriented by register theory, aim "to enhance students' overall academic and professional English application abilities” [1]. GCET divides ESP courses into 2 categories: Academic English (AE) and Professional English (PE), and AE is subdivided into General Academic English(GAE) and Special Academic English (SAE). Correspondingly, ESP has 3 teaching levels: basic, enhance and developed. Universities enjoy some autonomy in their courses construction. Shouren Wang thought that the concept of "English application ability" in GCET, based on register theory, combined language ability and language application ability and thus avoided the isolation of them. Wang furthered his discussion by subdividing GE and ESP according to their registers: GE included English used in individual and social register, and ESP included English used in academic and professional register[2]. GCET's threecurriculum theory settles the long-term disputes about the relationship between GE and ESP[3]. It seems that GCET adopts Weishen Yu's viewpoint: GE and ESP both intended to cultivate the students' language application ability, therefore, GE was not the basis of ESP and ESP was not the application of GE [4].

For teaching evaluation, GCET organically integrates summative test with formative test. It splits teaching evaluation into two closely related systems: course evaluation system and English ability evaluation system [5]. The former 
covers the whole process of the curriculum system and main participants while the latter mainly involves students' English ability tests, including the tests designed, developed or implemented by professional test institutes and the diverse school-based tests.

For teaching methods and means, Chinese college English teachers have been experimentally exploring the feasibility of blending college English teaching with modern education technology. Jing Zhu and Xiaojun Su explained the reason why micro-lesson could benefit language teaching from the perspective of cognitive linguistics and explored to construct a micro-lesson mode [6]. Halyah Lu, having studied the feasibility of applying micro-class based "flipped-classroom" mode in college English teaching through analyzing "microclass" and "flipped-class", the features of college English teachers and students, the current college English teaching mode together with the teaching environment, pointed out that in China micro-lesson and flipped class should be introduced and they definitely would enhance college English teaching quality [7]. In China, many teachers have begun to put microlesson mode into practice [8]. Some teachers even have extended their teaching to mobile terminals. Congzhong Sun pointed out that teaching informationization had positive effects on the improvement of college English classroom, and mobile terminal APPs together with social software had made blended teaching model within reach[9]. GCET summarizes the achievements and experiences in utilizing modern education technology in college English teaching. Obviously, GCET has a positive attitude towards modern education technology and it believes that, with the help of modern technology, college English teaching will be benefited, therefore, GCET advocates student-centered pedagogy and the hybrid of online and offline education. It "encourages teachers to construct and use micro-lessons, flipped class, MOOCs, and high-quality online education resource" [1].

\section{ENGLISH FOR GENERAL INTERNATIONAL BUSINESS LAW COURSE CONSTRUCTION AND PRACTICE}

\section{A. Course Nature: Special Academic English Driven by Content}

Peiying Ji, when introducing Fudan University ESP practice, thought that, owing to the relative insufficiency of capable teachers and the relative poor students' English ability, general local universities might not be suitable for GAE. If students did have needs, general local universities might squeeze some GAE into GE curriculums. She strongly suggested that general local universities offered PE courses[10].

However, KU has different ideas. KU is an applicationoriented general local university. Its application nature does not support the necessity of GAE, and its undergraduate degree education confirms the necessity of SAE.

The construction SAE course involves the understanding of SAE. It is commonly believed that SAE can be subdivided into the humanities and social sciences English, economics and business English and science and technology English
[11].But the above positioning of SAE in both teaching and learning is driven by language, namely, language is the core and the subject of teaching and learning rather then the knowledge conveyed by language. This pedagogy isolates language learning from knowledge learning, which contributes to the present ironic test-oriented college English teaching model and makes English teaching an example of "high-input but low output"[12]. On the contrary, The content-driven mode aims to obtain the information conveyed by language and improve language proficiency through the course content learning. Li-ming $\mathrm{Yu}$ and Jianxia Han, by doing empirical surveys and researches, concluded that content-driven mode was the core of ESP teaching for it was more efficient in improving learners' study enthusiasm, allowing them to achieve a systematic professional knowledge and ascending language application ability. They even regarded contentdriven mode as the road to the success of college English teaching[12].

Having taken the above theories and its present faculty and students situations into serious consideration, KU decided to choose English for General International Business Law (EGIBL) as one of its ESP starting points. The purpose of this course is to teach law by English rather than to teach English by law. It is an SAE course driven by content.

\section{B. Teaching Objectives and Teaching Requirements}

In accordance both to GCET and the course characteristics, EGIBL course aims to achieve or almost achieve the "enhanced level", and meanwhile, students should be able to understand the general international business law materials in English, to consult the business code to independently analyze and solve general international business legal issues or cases.

\section{EGIBL Course Design and Implementation}

The Course has undergone a winding road and was in hazard of abortion for a while. KU conducted a questionnaire survey among students who had passed CET-4 when deciding ESP courses. Students could make multiple choices. Students showed interests in CET-6, EGIBL and English for Speech and Debate (ESD). However, the students' final options were quite conflicting. (see Table)

TABLE I. ESP COURSES EOI AND ACtUAL CHOICE

\begin{tabular}{|c|c|c|}
\hline Course & Express of Interest & Actual choice \\
\hline CET-6 & 402 students & 155 students \\
\hline EGIBL & 262 students & 68 students \\
\hline ESD & 348 students & 37 students \\
\hline
\end{tabular}

The above situation forced the EGIBL to adjust its teaching objectives and requirements. While persisting in content-driven EGIBL direction, CET-6 was added. This change stabilized students, and subsequently, more students moved to this course from ESD. Students explained their reasons that ESD did not involve CET-6.

At present, EGIBL course framework is clear. It is a compulsory optional course for those students who have passed CET-4. EGIBL will be implemented in two semester with two phases: EGIBL + CET-6 (64 credit hours) and EGIBL+ legal English listening and speaking (64 credit hours). 


\section{Course Evaluation and Tests}

- Course evaluation covers all aspects of the course system, including the students' evaluation, peer review, expert evaluation, teaching management, etc.

- Tests consist of common basic test, on-campus tests, basic English tests and specific English tests. Common basic test refers to nationwide CET-6. On-campus tests include the routine class tests and final exams. The basic English test will be held in the phase of "EGIBL + CET-6”, while special English test will be held in "EGIBL+ legal English speaking and listening” phase.

\section{E. Teaching Methods and Means}

The course will be carried out by a variety of methods including task-based teaching, cooperation-based, projectbased teaching, and research-based teaching meanwhile micro-lessons and flipped class will be involved.

For EGIBL, before textbook study, the instructor will explain the related vocabulary and the relevant legal terminologies. Then students will be required to prepare preview questions by self-studying. When studying textbook, the teacher will guide students to find the answers to the preview questions by introducing legal cases and class legal practices, for example, moot court, business legal consultation, legal document preparation, etc. In addition, teachers will make and upload micro-lessons and use mobile terminals to carry out in-class tests.

\section{RESULTS AND DISCUSSION}

EGIBL course has been implemented for a semester and obtained satisfying early achievements. The data collected in this semester will enlighten its future adjustments.

\section{A. Mid-term Student Course Evaluation}

In the Mid-term course evaluation, the students admitted that they not only reaped the systematic legal knowledge but also enhanced English proficiency, and they averagely graded it 96 points, the same as CET-6 course. If course maturity degree, knowledge difficulty and knowledge span are compared, EGIBL course is definitely a wonder.

\section{B.Final Examination}

In the final examination of the semester, students achieved amazing academic performances both in English proficiency and international business law study.

Previously, students considered it very hard to pass CET-6. And the truth is that, for KU, the CET-6 passing rate is less than 5 percent. At the end of the semester, in order to evaluate whether the content-driven EGIBL course could effectively enhance students' English proficiency, a test paper was intentionally prepared. All the test materials were randomly selected from the previous CET-6 test papers. The result was as follows: $69.2 \%$ of the students passed and the average score of the exam was 66.3. Compared with the CET-6 passing rate of $\mathrm{KU}$, the results of the final exam is really inspiring.
In the international business law examination, the test paper included two parts:

- terminology translation: students were required to translate the terminologies from English to Chinese or vice versa. This part intended to test whether students could understand the correspondence of terminologies in two languages.

- questions: students were required to answer 10 questions related to international business law briefly in English, for example, "what are the three principle international business transactions?", "what is unlimited joint and several liability?", and etc. This part was designed to test how well students had mastered the general international business law concept leaned in this semester.

The results of the exam showed that $80 \%$ of the students passed the exam and the average score was 71 . One thing worth mentioning is that the students knew little about international business law before this course. Now not only did they understand some of the general international business law knowledge, but also could they express what they had learned in English. According to some professors of KU, it is hard for Chinese students to learn international business law In Chinese, let alone in English, and they have to admit that the outcome of this course and the students' performance are nothing but stunning.

\section{Final Course Evaluation}

At the end of the semester, student course evaluation was performed again because it was indispensible for us to know how students felt about the course, how well they could follow the instructor and, most importantly, where and how the course should be adjusted.

The following 6 questions were asked and answered:

- Which teaching mode benefits you more in improving your English proficiency? Content-driven mode or the language-driven mode?

- Which teaching mode benefits you more in improving your comprehensive ability? Contentdriven mode or language-driven mode?

- What are the advantages of this course?

- In which way should this course be improved?

- If you are allowed the $2^{\text {nd }}$ chance to choose your course between CET-6 and EGIBL, will you still choose EGIBL?

- Will you recommend this course to other students?

$68 \%$ of the students thought that language-driven mode benefited them better than content-driven mode;58\% thought that content-driven mode was superior in comprehensive ability training; $90 \%$ would be determined to choose this course again even if they were given the second consideration; $100 \%$ were willing to recommend this course to other students. For the advantages, most students agreed that this course was far more interesting than other language courses for they could learn both language and law. For the improvement, the 
students wanted more cases, more videos to interest the tedious legal rules and more chances to practice their oral English.

The results of the Final Evaluation sound contradictory at the first sight. But after the second thought, they make sense. Students are getting to know the advantages of content-driven mode even if they can not escape from the old cage immediately. Students do need and like this course and they have confidence in that this course will eventually help them not only in improving English proficiency but also in grasping general international business law. The results, in addition, prove that EGIBL+ legal English listening and speaking, the $2^{\text {nd }}$ phase in the next semester is on the right track for it is where and when videos and oral practices will be integrated. Of course, in the next semester, more cases should be included into the lectures so that students will keep their enthusiasm on this course.

\section{Micro-lessons, flipped class and Mobile Terminal Teaching}

In this semester, micro-lessons were not ready because EGIBL course construction was in the process of modifying. Now the adjustments have almost done, the micro-lessons are on the way. At the beginning of next semester, they will be accessible.

Flipped class has been carried out all the time and next semester more flipped teaching modes will be applied.

For mobile terminal teaching, an APP "Micro-Teaching Assistant" has been introduced. The final student evaluation actually was done on it. Once the teacher released questions, students received them and answered on their mobile terminals Next semester, many class tests and peer review will be done with the help of the APP.

\section{CONCLUSION}

In accordance with GCET, KU, by taking English for General International Business Law course as a breakthrough, effectively explores the feasibility and methods of ESP course construction in general local universities. It turns out that the general local universities can implement content-driven SAE education while CET-6 has to be integrated and more ways should be explored to make the tedious legal regulations alive and vivid. Up to now, the course construction of EGIBL has reaped some early harvest. The experience and data collected in this semester, together with the coming results of nationwide CET-6 will further shape and polish the present EGIBL course construction. Therefore, there is reason to believe that the course construction of EGIBL will be more promising after further adjustments.

\section{REFERENCES}

[1] Guidelines on College English Teaching [EB/OL].(2017-02-03) http://doc.orz520.com/a/doc/2017/0203/2082496.html?from=haosou. (In Chinese)

[2] Shouren Wang, "The key points of Guidelines on College English Teaching,” Foreign Language World, No.3, pp.2-10, 2016 (General Serial No.174). (In Chinese)

[3] Qiufang Wen, "The issues and solutions to the disputes of General English and Specific English in College English teaching,"Foreign Languages and Their Teaching, No.1, pp.1-8 ,2014. (In Chinese)

[4] Weishen $\mathrm{Yu}$, "The reconsideration of the impact of syllubus on English application ability training in college English teaching,” College English Teaching Research, No. 1, pp. 23-25, 2016. (In Chinese)

[5] Hongyong Yan and Xiuyan Qu, "An interpretation on College English talent training models in Guidelines on College English Teaching," Economic Research Guide, No. 8, pp. 59-60, 2017. (In Chinese)

[6] Jing Zhu and Xiaojun Su, "The Construction and Application of Microclass Mode of Instruction --With a Focus on College English Visualaural-oral Course,” Media in Foreign Language Instruction, No. 51, pp.21-25, 2015. (In Chinese)

[7] Halyah Lu, "Feasibility Analysis on the Application of Micro-class Based 'Flipped Classroom' Mode in College English Teaching,” Media in Foreign Language Instruction, No. 4, pp.33-36,2014. (In Chinese)

[8] Fengying Zhu, Xianzhong Wu and Jingmei Cui, "Construction of the Information Service Platform of College English Micro-Lectures," Information Science, No. 12, pp. 106-110, 2015. (In Chinese)

[9] Congzhong Sun, "Research on the 'Ketangpai' APP Applied in the College English Classroom,” Journal of Hubei Adult Education College, No. 3, pp.76-80, 2017.

[10] Peiying Ji, "ESP course construction under the framework of Guidelines on College English Teaching,” Foreign Language World, No.3, pp.16-21, 2017. (In Chinese)

[11] Youzhong Song and Liwen Li, "CBI / ESP and the reform of China's college English teaching,” Foreign Language Research, No.5, pp.1-4, 2011. (In Chinese)

[12] Liming $\mathrm{Yu}$ and Jianxia Han, "Content-driven or language driven: thoughts on Chinese college English Teaching," Foreign Languages and Their Teaching, No. 3, pp.1-4, 2012. (In Chinese) 